\title{
Hakikat Pendidikan Sepanjang Hayat Untuk Ditanamkan Pada Siswa Sekolah Dasar
}

\author{
Husaen Sudrajat ${ }^{1}$, Risa Herlina Hariati ${ }^{2}$ \\ PGMI, STAI Al-Amin Gersik Kediri, Mataram, Indonesia; \\ husaen.sudrajat@gmail.com; risa.herlina.hariati@gmail.com
}

\begin{abstract}
Abstrak: Pemahaman tentang apa itu belajar merupakan salah satu penyebab mengapa siswa merasa malas untuk belajar, baik itu belajar di sekolah maupun bbelajar di rumah. Salah satu penyebab yang juga tidak kalah mempengaruhi dalam memberi andil dalam penanaman konsep pendidikan terutama Pendidikan sepanjang hayat atau long life education pada diri siswa adalah sering hilangnya kesadaran pada guru untuk menjadikan pribadinya sendiri sebagai pribadi yang memegang kuat konsep Pendidikan sepanjang hayat. Dari latar belakang tersebut rumusan masalah yang akan di teliti adalah bagaimana hakikat dari Pendidikan sepanjang hayat untuk menanamkan konsep long-life education pada anak di sekolah dasar. Adapun tujuan dari penelitian ini adalah untuk memberikan gambaran hakikat Pendidikan sepanjang hayat dalam menanamkan konsep long-life education di sekolah dasar. Metode penelitian yang digunakan adalah jenis penelitian kualitataif dengan pendekatan deskriptif. Penelitian ini di lakukan pada sebuah sekolah dasar. Hasil penelitian menunjukkan Pendidikan sepanjang hayat dalam konteks siswa mempunyai dua makna, yakni pertama proses pendidikan yang berfokus pada motivasi anggota siswa untuk mendapatkan pengalaman belajar secara terus menerus dan berkelanjutan. Kedua, Pendidikan sepanjang hayat merupakan landasan yang kuat bagi program pendidikan pada siswa yang mengarah pada upaya untuk menumbuhkan masyarakat gemar belajar. Pendidikan sepanjang hayat merupakan prinsip yang menjadi dasar seluruh organisasi sistem pendidikan yang ada. Artinya pendidikan sepanjang hayat tidak mengenal batas kelembagaan dan program dalam sistem pendidikan. Dan hal yang perlu diperhatikan juga bahwa ketika seorang guru menginginkan siswanya menjadi seorang pembelajar sepanjang hayat (life long learnear), maka hal yang harus pertama kali disadari dan dilakukan oleh guru itu adalah menjadikan dirinya seorang pembelajar sepanjang hayat.
\end{abstract}

Kata Kunci: Pendidikan sepanjang hayat, siswa, sekolah dasar

Abstract: One of the problems that exist in learning at school with regard to understanding what learning is is one of the reasons why students feel lazy to study either at home or at school. One problem that also contributes to the inculcation of the concept of lifelong education in students is the teacher's frequent loss of awareness to make himself a person who firmly holds the concept of life long education. The formulation of the problem is how the nature of lifelong education is to instill the concept of long-life education in elementary school children. The purpose of this research is to provide an overview of the nature of lifelong education in instilling the concept of long-life education in elementary schools. The research method used is a qualitative research type with a descriptive approach. This research was conducted at an elementary school. The results of the study show that lifelong education in the context of students has two meanings, the first is an educational process that focuses on the motivation of student members to gain continuous learning experiences. Second, lifelong education is a strong foundation for educational programs in students that lead to efforts to grow people who like to learn. Lifelong education is a principle that forms the basis of the entire organization of the existing education system. In other words, lifelong education knows no institutional boundaries and educational system programs. When a teacher wants 
Vol.06-No.02-Desember-2021|Husaen Sudrajat ${ }^{1}$, Risa Herlina Hariati ${ }^{2}$

Al-Amin: Kajian Pendidikan dan Sosial Kemasyarakatan

his students to become lifelong learners. The first thing that the teacher must realize and do is make himself a lifelong learner.

Keywords: long life education, student, elementary school

\section{PENDAHULUAN}

Belajar sebagai kegiatan utama dalam dunia pendidikan seringkali dikaitkan dengan bahan ajar atau segala bentuk kegiatan yang berhubungan dengan bahan ajar. Belajar sering didefinisikan sebagai membaca buku, menulis kalimat, menghafal materi, atau memecahkan masalah matematika tertentu. Walaupun itu hanya sebagian dari kegiatan pembelajaran. Salah satu kendala dalam memahami apa itu belajar yang ada dalam dunia pendidikan khususnya di sekolah menjadi salah satu penyebab siswa menjadi semakin malas ketika belajar di rumah dan di sekolah.

Belajar sepanjang hayat merupakan sebuah konsep atau ide. Gagasan pokok dalam konsep ini adalah belajar itu tidak hanya berlangsung pada lembaga-lembaga pendidikan formal saja, tapi seseorang masih dapat memperoleh pengetahuan (jika orang yang bersangkutan berkenan) setelah ia selesai mengikuti pendidikan di suatu lembaga pendidikan formal tertentu. Belajar dalam arti sebenarnya adalah sesuatu yang berlangsung sepanjang kehidupan seseorang. Bedasarkan ide tersebut konsep belajar sepanjang hayat sering pula dikatakan sebagai belajar berkelanjutan (continuing learning).

Hal ini didasarkan pada konsep pendidikan sepanjang hayat yang dikembangkan oleh Johann Amoscomenius / 15921671 pada abad ke-16 dan John Dewey sekitar 40 tahun yang lalu yang menyatakan bahwa Pendidikan itu tidak diartikan sebagai program yang diselenggarakan oleh Lembaga formal saja, dan tidak ada pengertian yang menyatakan bahwa pembelajaran sebagai esensi pendidikan berkaitan dengan usia, pendidikan sekolah, atau jenis pembelajaran itu sendiri. Untuk memahami tentang ap aitu belajar, di perlukan adanya proses belajar terutama belajar sepanjang hayat.

Secara pedagogis pendidikan sepanjang hayat merupakan suatu konsep tentang belajar terus menerus dan berkesinambungan (continuing-learning) dari 
buaian sampai akhir hayat, dimana proses belajarnya sejalan dengan fase-fase pertumbuhan dan perkembangan yang terjadi dalam diri individu.

Belajar sangat erat kaitannya dengan psikologi (ilmu jiwa). Jiwa manusia terus berkembang sejalan dengan pertumbuhan jasmani manusia, sejak dari masa bayi, kanak-kanak, remaja, dewasa sampai masa tua. Dengan melalui tahap-tahap tertentu dan pada akhirnya anak tersebut mencapai kedewasaan baik dari segi kejiwaan maupun dari segi jasmani. Dalam perkembangan jiwa dan jasmani tersebut, manusia perlu yang namanya proses belajar. Masa belajar itu bertingkat, sejalan dengan fasefase pertumbuhan dan perkembangan manusia. Dapat dipahami bahwa belajar merupakan kebutuhan pokok sebagai bekal demi menempuh kehidupan di sepanjang hayat.

Sekolah dasar yang merupakan lingkungan kedua bagi siswa di samping lingkungan keluarga, turut andil dalam pembentukan pemahaman siswa sebagai awal pembentukan karakter siswa yang bersangkutan. Jika guru tidak membantu siswa mengatasi kesulitan dan masalah belajar, maka akan sulit pula bagi siswa untuk mengembangkan kegembiraan, keinginan dan semangat belajar. Jika siswa tidak senang dan tidak menunjukkan semangat terhadap proses pembelajaran yang dilakukannya, maka akan sulit mengembangkan keinginan untuk menerapkan konsep belajar sepanjang hayat.

Karena banyaknya tuntutan terutama materi yang harus disampaikan dan diselesaikan oleh guru kepada siswanya, guru cenderung lupa untuk menciptakan suasana pembelajaran yang mendukung perkembangan siswanya. Hal yang sering dilupakan atau jarang dilakukan oleh guru diantaranya memberikan motivasi terhadap keadaan siswa, memahami kesulitan belajar siswa, dan mencari solusi atas permasalahan yang berkaitan dengan belajar siswa. Guru harus terus mengembangkan kemampuannya, pengembangan kemampuan ini membutuhkan pelatihan dan peningkatan berkelanjutan oleh guru selama proses pembelajaran untuk memfasilitasi, membimbing dan memberikan Pendidikan yang maksimal kepada siswa. 
Vol.06-No.02-Desember-2021|Husaen Sudrajat ${ }^{1}$, Risa Herlina Hariati ${ }^{2}$

Al-Amin: Kajian Pendidikan dan Sosial Kemasyarakatan

Salah satu penyebab siswa tidak mampu mempelajari konsep pendidikan sepanjang hayat adalah seringnya hilangnya kesadaran guru untuk menjadikan pribadinya sendiri sebagai pribadi yang memegang kuat konsep life long education. Dari latar belakang yang sudah di kemukakan, peneliti membuat rumusan masalah berupa bagaimana hakikat dari Pendidikan sepanjang hayat untuk menanamkan konsep long-life education pada anak sekolah dasar. Adapun tujuan dari penelitian ini adalah untuk memberikan gambaran hakikat Pendidikan sepanjang hayat dalam menanamkan konsep long-life education di sekolah dasar.

\section{METODE PENELITIAN}

Metode penelitian yang digunakan adalah jenis penelitian kualitataif dengan pendekatan deskriptif. Penelitian ini di lakukan pada sebuah sekolah dasar yang berada di Lombok Tengah. Penelitian ini di lakukan dengan cara memberikan gambaran tentang hakikat Pendidikan sepanjang hayat yang nantinya akan di tanamkan pada jiwa peserta didik supaya mampu memahami konsep long-life education. Subjek penelitian ini adalah siswa dan guru yang berada di salah satu sekolah dasar.

\section{HASIL DAN PEMBAHASAN}

\section{Hakekat Pendidikan Sepanjang Hayat}

Secara pedagogis pendidikan sepanjang hayat merupakan suatu konsep tentang belajar terus menerus dan berkelanjutan atau berkesinambungan (continuing-learning) dari buaian sampai akhir hayat, dimana proses belajar tersebut sejalan dengan fasefase pertumbuhan perkembangan yang terjadi dalam diri individu. Dalam naskah UNESCO tentang institue for education (1979), dijelaskan bahwa pendidikan sepanjang hayat dikembangkan atas prinsip-prinsip pendidikan sebagai berikut:

a. Pendidikan hanya berakhir ketika manusia telah meninggalkan dunia.

b. Pendidikan sepanjang hayat merupakan motivasi yang kuat bagi siswa untuk merencanakan dan melakukan kegiatan belajar secara berkelanjutan dan sistimatis. 
c. Kegiatan belajar ditujukan untuk memperoleh, memperbaharui, dan atau meningkatkan pengetahuan, sikap dan keterampilan yang telah dimiliki dan harus dimiliki oleh siswa yang berhubungan dengan perubahan yang terus menerus sepanjang kehidupan.

d. Pendidikan memiliki tujuan berangkai dalam memenuhi kebutuhan belajar dan dalam mengembangkan kepuasan diri setiap insan yang melakukan kegiatan belajar.

e. Mendapatkan pendidikan yang layak merupakan parsyaratan bagi perkembangan kehidupan manusia, baik untuk memotivasi diri maupun untuk meningkatkan kemampuan yang telah dimiliki, agar manusia selalu melakukakan kegiatan belajar guna memenuhi kebutuhan hidupnya.

Pendidikan sepanjang hayat dalam konteks siswa memiliki dua implikasi. Yang pertama adalah proses pendidikan yang menitikberatkan pada motivasi siswa untuk memperoleh pengalaman belajar yang berkesinambungan (continuous learning). Pengalaman belajar ini secara sadar diprogramkan, diorganisasikan, dan dilakukan secara sistematis sepanjang proses kegiatan pembelajaran untuk mencapai tujuan pembelajaran yang telah ditentukan sebelumnya. Menurut Gestrelius (1977), belajar sepanjang hayat meliputi meliputi interaksi pembelajaran, penentuan bahan belajar dan metode belajar, tujuan pembelajaran, lembaga penyelenggara program pendidikan organisasi penyelenggaraan, fasilitas, sarana dan prasarana, administrasi dan kondisi lingkungan yang mendukung kegiatan belajar secara berkesinambungan. Pendidikan sepanjang hayat ini mencakup peran pendidikan dan peserta didik yang perlu belajar satu sama lain dan dapat belajar, mengelola kegiatan belajar, dan unsurunsur lain yang mendukung proses belajar yang efisien dan efektif.

Kedua, belajar sepanjang hayat merupakan landasan yang kuat bagi program pendidikan siswa yang mengarah pada upaya membangun masyarakat belajar. Orang-orang yang antusias terbentuk karena setiap anggota masyarakat terusmenerus mencari dan menemukan hal-hal baru dan bermakna dalam hidupnya, mengembangkan keterampilannya, dan tumbuh melalui kegiatan belajar. Kegiatan belajar sudah menjadi kebutuhan dalam kehidupan dan kebiasaan masyarakat. 
Kegiatan belajar telah menjadi bagian yang tidak terpisahkan dari kehidupan dan kebiasaan siswa. Kegiatan belajar yang dilakukan oleh setiap siswa hanya sebatas mengetahui dan belajar (learning to learn) dan belajar memecahkan masalah yang muncul dalam kehidupan siswa (learning to solve problem). Kegiatan belajar yang mereka lakukan sesuai dengan minat dan kemajuan mereka dalam hidup (learning how to be), belajar untuk melakukan sesuatu (learning how to do things), dan belajar untuk hidup bersama (learning how to live together).

\section{Konsep Pendidikan Sepanjang Hayat (Life Long Education)}

Pendidikan sepanjang hayat sebetulnya bukanlah sebuah konsep atau ide yang baru. Pada sekitar abad ke-14 tepatnya pada zaman Nabi Muhammad SAW, konsep tersebut telah riwayatkan dalam sebuah hadits yang artinya: Dari Abu Hurairah ra, dari Nabi Saw, beliau bersabda "Tuntutlah ilmu oleh kalian mulai dari buaian hingga liang lahat". (H.R. Muslim).

Ada berbagai metode dan proses yang dapat dilakukan dalam belajar namun sejatinya hal tersebut tetap menunjukkan bahwa belajar pada dasarnya adalah seumur hidup. Tidak ada batasan usia yang menghalangi seseorang untuk terus belajar. Bahkan guru yang lebih tua yang mencoba untuk menemukan, mempelajari, dan memahami perkembangan siswa, atau menemukan cara yang efektif untuk mengajar mata pelajaran mereka, menunjukkan bahwa belajar tidak dibatasi usia. Artinya, guru pun harus senantiasa mengembangkan dan terus meningkatkan kemampuannya baik keterampilan pedagogik maupun profesionalisme. Dorongan untuk belajar sepanjang hayat muncul karena dirasakan sebagai kebutuhan. Setiap orang merasa perlu untuk memenuhi kebutuhan hidupnya, serta tertantang untuk beradaptasi secara positif, dinamis, kreatif dan inovatif terhadap kemajuan zaman. Artinya, guru harus mampu beradaptasi dengan perubahan zaman. Dengan kata lain, pendidikan adalah bagian esensial dari kehidupan itu sendiri.

Pendidikan sepanjang hayat juga dapat didefinisikan sebagai tujuan atau ide formal untuk mengorganisir, menyusun, atau mensistematisasikan pengalaman pendidikan. Organisasi dan struktur telah diperluas untuk mencakup semua 
kelompok umur, dari yang termuda hingga yang tertua. (Tirtarahardja, 2005: 37). Pendidikan sepanjang hayat didasarkan pada keyakinan bahwa pendidikan tidak hanya dengan pendidikan sekolah, tetapi pendidikan sepanjang hayat adalah proses sepanjang hayat dan berkesinambungan. Gagasan pendidikan sepanjang hayat abad ke-14 yang lalu dikemukakan oleh John Amos Comenius, seorang pendidik abad ke5 yang lalu (abad ke-16 / 15921671), dan John Dewey sekitar 60 tahun yang lalu (1950an). Comenius mencetuskan konsep pendidikan bahwa pendidikan adalah untuk membuat persiapan yang lebih berguna di akhirat nanti. (Cropley, 2001: 67).

Pembelajaran sepanjang hayat merupakan prinsip yang menjadi bagian mendasar dari semua organisasi dalam sistem pendidikan yang ada. Dengan kata lain, pendidikan sepanjang hayat tidak mengenal batas-batas sistem atau program sistem pendidikan. Filsuf dan pendidik Amerika John Dewey (1859-1952) percaya bahwa hal terpenting dalam dunia pendidikan adalah aktivitas anak-anak itu sendiri. Ini adalah manifestasi dan penerapan kehidupan. Tidak ada kehidupan tanpa aktivitas. Harus ada aktivitas dan aktivitas sepanjang hidup. Anak-anak harus memperoleh pengetahuan mereka sendiri. (Hasan, 2007: 2) Pada 1970-an, Ketua Komisi Internasional untuk Pendidikan dan Pembangunan, Edgar Faure, membuat enam rekomendasi untuk memprediksi dunia dalam laporannya tahun 1972 UNESCO, Learning To Be, The World of Education, Today and Tomorrow. Salah satu rekomendasinya adalah belajar sepanjang hayat. (UNESCO, Jawed, 1996: 5354). Reaksi masing-masing negara terhadap usulan tersebut tidak sama. Reaksi Indonesia sendiri terhadap konsep pendidikan sepanjang hayat sangat positif, yang tercermin dalam kebijakan nasional khususnya Ketetapan MPR IV/MPR/1973. Ketetapan MPR No. IV/MPR/1978 tentang GBHN menyatakan bahwa prinsip-prinsip pembangunan nasional meliputi: Dalam Bab IV bagian Pendidikan, butir (d) menyatakan: Pendidikan berlangsung sepanjang hayat dan dilaksanakan di dalam lingkungan rumah tangga/siswa dan masyarakat, karena itu pendidikan menjadi tanggung jawab bersama antara siswa, masyarakat, dan pemerintah.. Kebijakan Pembangunan Nasional Bidang Pendidikan menetapkan bahwa GBHN harus dilaksanakan secara 
Vol.06-No.02-Desember-2021|Husaen Sudrajat ${ }^{1}$, Risa Herlina Hariati ${ }^{2}$

Al-Amin: Kajian Pendidikan dan Sosial Kemasyarakatan

konstitusional oleh lembaga pendidikan formal, informal, dan informal. Masingmasing lembaga ini saling melengkapi.

\section{Penanaman konsep belajar sepanjang hayat ke dalam kelas}

Memahami perkembangan dan masalah siswa penting bagi guru untuk menemukan dan menentukan arah pembelajaran dan memberikan gambaran kepada guru untuk memberikan motivasi terhadap kondisi mereka. Seperti yang dikemukakan Setiawati dan Chudari (2007:41), teknik pemahaman perkembangan siswa terdiri dari teknik tes dan non tes. Teknik tes terdiri dari tes bakat, tes kecerdasan, dan tes keberhasilan belajar, sedangkan teknik non tes dapat dilakukan melalui observasi, wawancara, angket, autobiografi, anekdot, pengukuran sosial, dan studi kasus. Teknik memahami perkembangan siswa dapat digunakan secara terpadu dalam proses pembelajaran sehingga guru tidak sadar sedang berusaha memahami perkembangannya. Misalnya, menggunakan autobiografi, autobiografi ini berfungsi untuk memahami perkembangan siswa juga dapat digunakan untuk melatih keterampilan menulis siswa. Autobiografi adalah karangan pribadi yang berisi pernyataan pribadi siswa tentang pengalaman hidup, aspirasi, keadaan siswa, dan lainnya. (Setiawati \& Chudari: 57) karangan pribadi ini merupakan salah satu cara untuk memahami kondisi pribadi siswa dan umumnya bersifat rahasia. Artinya hanya siswa itu sendiri yang tahu. Penggunaan autobiografi bagi guru bertujuan untuk menemukan status siswa yang berkaitan dengan minat, keinginan, bakat, keterampilan, sikap, dan pengalaman hidupnya dengan teman sekelas, guru, atau sekolah.

\section{Guru sebagai Role Model Pembelajar Sepanjang Hayat}

Secara sederhana, istilah "role model" adalah contoh atau panutan. Yang sebenarnya sudah diajarkan oleh pendahulu kita, terutama bapak Pendidikan kita, Ki Hajar Dewantoro, yang mengajarkan mengajarkan "Ing Ngarso Sung Tulodo, Ing Madya Mangun Karso dan Tut Wuri Handayani" Ajaran pertama yang disampaikan adalah "Ing Ngarso Sung Tulodo" yang terjemahannya adalah "di depan memberikan teladan" atau bisa juga diartikan sebagai guru harus memberikan teladan bagi siswanya. Artinya guru harus menjadi panutan siswa. Menurut Wikipedia, panutan adalah "seseorang 
yang bertindak sebagai panutan yang berperilaku ditiru oleh orang lain." Deporter (2005: 39) dalam pepatah mengatakan, "Tindakan lebih utama daripada kata-kata," sebagai contoh. Perilaku guru lebih penting daripada ucapan guru itu sendiri. Semakin banyak guru memberi teladan atau memberikan contoh secara langsung, semakin siswa tertarik dan menjadikannya contoh lalu mengikutinya. Siswa akan merasa tertarik karena mereka merasakan kesamaan, kecocokan antara keyakinan dan ucapan guru dengan perbuatannya. Oleh karena itu, memberi panutan atau memberi contoh langsung adalah cara yang ampuh untuk membangun hubungan dan memahami orang lain, terutama antara guru dan siswa. Keteladanan meningkatkan proses belajar. Jika seorang guru menginginkan seorang siswa menjadi pembelajar sepanjang hayat, hal pertama yang harus dilakukan guru adalah mengenali dan bertindak sebagai pembelajar sepanjang hayat.

\section{Kesimpulan}

Belajar adalah upaya untuk melakukan perubahan berdasarkan pengalaman berinteraksi dengan lingkungan. Oleh karena itu, sebagaimana konsep pendidikan sepanjang hayat, tidak ada batasan usia untuk terus belajar. Untuk dapat menyampaikan konsep pendidikan sepanjang hayat, perlu adanya kesinambungan antara teknik pengajaran yang menggunakan Metode yang berfokus pada siswa dan peran guru sebagai role model dalam Pendidikan sepanjang hayat. Salah satu cara guru sekolah dasar dapat menciptakan lingkungan belajar dengan nuansa yang kondusif dalam proses pembelajaran adalah dengan terlebih dahulu mencari dan memahami perkembangan siswa dengan menggunakan berbagai teknik yang ada bagi guru. Penggunaan metode dan teknik yang tepat akan menumbuhkan kegembiraan dan antusiasme siswa untuk proses belajar. Metode dan Teknik yang tepat juga dapat meningkatkan minat dan bakat siswa dalam belajar. Terakhir, gurulah yang harus pertama kali menjadi pembelajar sepanjang hayat, sebelum ia mengajak siswa-siswanya.

\section{SARAN}


Vol.06-No.02-Desember-2021|Husaen Sudrajat ${ }^{1}$, Risa Herlina Hariati ${ }^{2}$

Al-Amin: Kajian Pendidikan dan Sosial Kemasyarakatan

Penulis berharap kedepannya guru mampu memilah dan memilih strategi pembelajaran yang lebih menarik dalam memberikan hakikat pembelajaran sepanjang hayat yang harus mulai di tanamkan dari pendidikan dasar. Penulis juga berharap adanya kajian atau penelitian lebih lanjut tentang hakikat dari pembelajaran sepanjang hayat guna untuk memberikan motivasi tentang kegiatan belajar yang sejatinya bisa dilakukan dimana saja dan kapan saja.

\section{DAFTAR PUSTAKA}

Ardiwinata, S Jajat dan Ahmad Hufad. 2008. Sosiologi dan Antropologi Pendidikan. Bandung : UPI PRESS

Cropley. 2001. Pendidikan sepanjang Hayat, Penyunting M. Sarjan Kadir. Surabaya : Usaha Nasional.

Tirtarahardja, U. 2005. Pengantar Pendidikan. Jakarta: Rineka Cipta.

DePorter, B., Reardon M., \& Nourie S.S. 2005. Quantum Teaching: Mempraktikan Quantum Learning di Ruang-ruang Kelas. Kaifa: Bandung.

Hasan, M. T. 2007. Islam dalam Perspektif Sosial Budaya. Jakarta: Galasa Nusantara

N.K. Singh dan Mr. A.R. Agwan. 2000. Encyclopaedia of the Holy Qur'ân. New Delhi: balaji

Offset Byrne, R. 2007. The Secret. Jakarta: PT Gramedia.

Prayitno, E. 1989. Motivasi Dalam Belajar. Jakarta: P2LPTK

Robert H. Lauer. 2002. Perspektif Tentang Perubahan Sosial. (Terjemahan). Jakarta: Panca Karya.

Santrock,J.W. 2010. Psikologi Pendidikan. Prenada Media Grup: Jakarta.

Sardiman, A,M. 1990. Interaksi dan Motivasi Belajar Mengajar. Jakarta: Rajawali

Setiawati \& Chudari, I.N. 2005. Bimbingan dan Koseling. Bandung: UPI Press

Sudjana D. 2004. Wawasan, Sejarah perkembangan, Filsafat, Teori pendukung, Asas Pendidikan Nonformal. Bandung: Falah Produksi.

Sulaeman, MI. 1980. Pendidikan Dalam Keluarga. Makalah Seminar diterbitkan oleh IKIP Bandung Press.

UNESCO, Dalam Jawed, Muhammad, (Ed.). 1996. Year Book of the Muslim World: A Handy Encyclopaedia, New Delhi: Medialine.

Vembriarto. 1990. Foundamental Of Family Education. New York: Printihal, Inc. 